\title{
PENGARUH MARKET VALUE, LEVERAGE DAN ASSETS MANAGEMENT TERHADAP FIRM VALUE DENGAN KEBIJAKAN DIVIDEN SEBAGAI VARIABEL MODERASI
}

\author{
Fanny \\ Program Studi Magister Manajemen Universitas Tarumanagara \\ fannyymv@gmail.com \\ Indra Widjaja \\ Program Studi Magister Manajemen Universitas Tarumanagara \\ Masuk : 07-12-2019, revisi : 21-12-2019 diterima untuk diterbitkan : 21-12-2019
}

\begin{abstract}
An established company has two goals, short term and long term goals. In the longterm goals, the company will try to maximize the value of the company. Maximizing firm value is essential for company because it means increasing the wealth of shareholders as well. This study examines the effect of market values, leverages, and management asset into the firm's value with dividend policy as a moderating variable. For this purpose, the firms in the subsector chemical listed in Indonesia Stock Exchange during the period of 2009 - 2018 are examined. The sampling method was done by using purposive sampling. Secondary data collection methods were taken from IDX published financial statements. This research used multiple regression analysis with fixed effect method to test their hypothesis using Eviews 9.0. The results show that earning per share has a negative significant effect to firm value in which is measured by price to book the value, while leverage and management assets have a positive significant impact to the firm' value. F-test result shows that all independent variables in this research simultaneously has a significant effect to firm's value with dividend policy as a moderating variable in sub sector chemical estate listed in Indonesia Stock Exchange. In the test of Adjusted R2, the analysis results showed that $43.41 \%$ firm's value was influenced by the independent variables of this research while the remaining is influenced by other factors which are not studied.
\end{abstract}

Keywords : Market Value, Leverage, Asset Management, Dividend Policy, Firm Value

\begin{abstract}
Abstrak : Perusahaan didirikan untuk mencapai tujuan perusahaan baik tujuan jangka pendek, maupun jangka panjang. Tujuan jangka panjang adalah memaksimalkan nilai perusahaan. Memaksimalkan nilai perusahaan sangat penting bagi perusahaan karena juga berarti meningkatkan kekayaan pemegang saham. Penelitian ini menguji pengaruh market value, leverage, dan assets management, terhadap firm value dengan kebijakan dividen sebagai variabel moderasi. Penelitian ini meneliti pada perusahaan - perusahaan di sub sektor kimia yang terdaftar di Bursa Efek Indonesia selama periode 2009 - 2018. Metode pengambilan sampel dilakukan dengan menggunakan purposive sampling. Metode pengumpulan data sekunder diambil dari laporan keuangan yang diterbitkan BEI. Penelitian ini menggunakan analisis regresi berganda dengan metode fixed effect untuk menguji hipotesis dengan menggunakan Eviews 9.0. Hasil penelitian ini menunjukkan bahwa earning per share memiliki pengaruh yang negatif dan signifikan terhadap firm value yang diukur oleh price to book value, sementara leverage, dan assets management memiliki pengaruh positif dan signifikan terhadap firm value. Hasil uji-F menunjukkan bahwa semua variabel independen dalam penelitian ini secara simultan memiliki pengaruh yang signifikan terhadap firm value dengan kebijakan dividen sebagai variabel moderasi pada peruahaan sub sektor kimia yang terdaftar di Bursa Efek Indonesia. Dalam pengujian Adjusted $\mathrm{R}^{2}$, hasil analisis menunjukkan bahwa $43.41 \%$, firm
\end{abstract}


value dipengaruhi oleh variabel independen dalam penelitian ini sedangkan sisanya dipengaruhi oleh faktor lain yang tidak diteliti pada penelitian ini.

Kata Kunci : Market Value, Leverage, Assets Management, Kebijakan Dividen, Firm Value

\section{Latar belakang}

Sekarang ini Bursa Efek Indonesia (BEI) mengajak seluruh masyarakat Indonesia melalui kampanye Yuk Nabung Saham (YNS) untuk mulai berinvestasi di pasar modal. Yuk Nabung Saham (YNS) merupakan kampanye untuk mengajak masyarakat sebagai calon investor untuk berinvestasi di pasar modal dengan membeli saham secara rutin dan berkala. Dengan memberikan pengetahuan kepada masyarakat mengenai seluk beluk investasi pasar modal, BEI ingin meningkatkan kesadaran akan pentingnya berinvestasi saham, menaikkan jumlah investor lokal juga menyejahterakan perekonomian masyarakat Indonesia.

Putra (2014) menyatakan bahwa pada umumnya suatu perusahaan akan selalu berusaha untuk mencapai tujuannya. Perusahaan didirikan dengan maksud mencapai tujuan perusahaan baik tujuan jangka pendek, maupun jangka panjang. Tujuan jangka pendek perusahaan adalah dapat memperoleh keuntungan yang semaksimal mungkin dengan pemanfaatan sumber daya yang dimiliki oleh perusahaan. Tujuan jangka panjang adalah memaksimalkan nilai perusahaan. Nilai perusahaan merupakan hasil dari kinerja perusahaan tersebut dalam satu periode. Semakin baik kinerja keuangan suatu perusahaan maka semakin mudah untuk menarik investor untuk menginvestasikan dananya pada perusahaan. Karena diharapkan semakin baik kinerja suatu perusahaan maka nilai saham akan meningkat, dan memberikan return yang diharapkan oleh investor.

Untuk memaksimalkan nilai perusahaan, perusahaan perlu memperhatikan banyak faktor, salah satunya adalah kondisi fundamental perusahaan. Kondisi fundamental perusahaan merupakan kondisi dari internal perusahaan seperti kondisi keuangan. Menganalisis rasio keuangan adalah suatu cara yang dapat dilakukan untuk mengetahui kondisi keuangan perusahaan. Sedangkan faktor eksternal (makro) yang dapat memaksimalisasi nilai perusahaan berupa tingkat bunga, fluktuasi nilai valas dan keadaan pasar modal. Namun penelitian ini hanya berfokus pada kondisi fundamental perusahaan atau faktor internal perusahaan.

Earning per share merupakan salah satu indikator yang digunakan oleh investor dalam sebelum membuat keputusan investasi pada saham perusahaan. Earning per share yang tinggi akan lebih menarik perhatian investor ketimbang earning per share yang rendah, sehingga menarik investor untuk menanamkan modalnya. Dapat dikatakan earning per share juga berpengaruh terhadap nilai perusahaan di mata investor.

Leverage dapat diartikan sebagai penggunaan aktiva atau dana dimana untuk penggunaan tersebut perusahaan harus menutup biaya tetap atau membayar beban tetap. Dengan menggunakan leverage, nilai perusahaan akan meningkat karena adanya manfaat perlindungan pajak.

Fama dan French (1998) menyatakan bahwa optimalisasi nilai perusahaan ini dapat dicapai melalui pelaksanaan tiga fungsi keuangan dimana satu keputusan keuangan yang diambil akan mempengaruhi keputusan keuangan lainnya dan akan berdampak pada nilai perusahaan.

Salah satu bagian penting manjemen yang ada pada suatu perusahaan adalah manajemen aset. kebijakan manajemen aset dapat mendukung upaya perusahaan untuk meningkatkan produktivitas dan efisiensi biaya produksi dan operasional perusahaan yang selanjutnya dapat meningkatkan kemampulabaan perusahaan, yang berujung pada peningkatan pertumbuhan penjualan dan nilai perusahaan.

Riyanto (2011) menyatakan bahwa kebijakan dividen dipengaruhi oleh kebutuhan dana untuk membayar utang yang berdampak pada pembayaran dividen, apabila perusahaan mampu melunasi hutang-hutangnya, maka perusahaan juga akan mampu membagikan dividen. 
Dari uraian di atas, tujuan dari penelitian ini adalah mencoba membuktikan apakah ada pengaruh signifikan dari market value, leverage, assets management terhadap firm value dengan variabel moderasi kebijakan dividen. Berdasarkan hal tersebut penulis tertarik melakukan penelitian dengan judul : "PENGARUH MARKET VALUE, LEVERAGE, ASSETS MANAGEMENT, TERHADAP FIRM VALUE DENGAN KEBIJAKAN DIVIDEN SEBAGAI VARIABEL MODERASI"

\section{Tujuan Penelitian}

Tujuan penelitian yang hendak dicapai melalui penelitian ini adalah:

1. Untuk mengetahui apakah firm value dapat mempengaruhi market value.

2. Untuk mengetahui apakah terdapat pengaruh leverage terhadap firm value.

3. Untuk mengetahui apakah terdapat pengaruh assets management terhadap firm value.

4. Untuk mengetahui apakah kebijakan dividen memoderasi hubungan leverage terhadap firm value.

5. Untuk mengetahui apakah terdapat pengaruh market value, leverage dan assets management secara bersama-sama terhadap firm value dengan kebijakan dividen sebagai variabel moderasi.

\section{Penelitian Terdahulu}

Tabel 1

Ringkasan Penelitian Sebelumnya

\begin{tabular}{|l|l|l|}
\hline Variabel & Diteliti Oleh & Terhadap firm value \\
\hline Earning per share & Ekaprastyana \& Anwar (2017) & positif \& signifikan \\
\hline Earning per share & Islam, et al (2014) & negative dan tidak signifikan \\
\hline Earning per share & Nuraeni (2016) & positif \& tidak signifikan \\
\hline leverage & Winarto (2015) & positif dan signifikan \\
\hline leverage & Sukma \& Teguh (2014) & tidak signifikan \\
\hline leverage & Bhekti Fitri Prasetyorini (2013) & negative dan signifikan \\
\hline leverage & Pratama dan Wiksuana (2016) & positif dan signifikan \\
\hline Assets management & Kurniasari (2017) & positif dan signifikan \\
\hline Assets management & Erawati (2015) & negative dan tidak signifikan \\
\hline Kebijakan dividen & Putri Andika Raharjo (2016) & $\begin{array}{l}\text { tidak memoderasi pengaruh keputusan } \\
\text { pendanaan (DER) }\end{array}$ \\
\hline
\end{tabular}

\section{Tinjauan Pustaka}

\section{Market Value}

Market value atau rasio nilai pasar adalah rasio yang terkait dengan penilaian kinerja saham perusahaan yang setelah diperdagangkan di pasar modal (go public). Jenis rasio market value yang digunakan dalam penelitian ini yaitu earning per share (EPS). Rumus yang digunakan adalah:

$$
\mathrm{EPS}=\frac{\text { Laba Bersih }}{\text { Jumlah Saham Beredar }}
$$

\section{Leverage}

Leverage adalah rasio yang mengukur berapa besar penggunaan hutang dalam pembelanjaan perusahaan. Jenis rasio leverage yang digunakan dalam penelitian ini yaitu debt to equity ratio (DER). Rumus yang digunakan adalah :

$$
\mathrm{DER}=\frac{\text { Total Debt }}{\text { Total Equity }}
$$

\section{Assets Management}

Assets Management adalah kemampuan perusahaan untuk mengelola asetnya secara efektif dan efisien untuk mencapai satu tujuan. Dimensi yang digunakan dalam assets 
management dalam penelitian ini adalah total assets turnover (TATO). Total assets turnover dalam penelitian ini diukur sebagai berikut:

$$
\mathrm{TATO}=\frac{\text { Sales }}{\text { Total Assets }}
$$

\section{Firm Value}

Menurut Sudana (2011:8), nilai perusahaan adalah nilai sekarang dari arus pendapatan atau kas yang diharapkan diterima pada masa yang akan datang. Jenis alat ukur nilai perusahaan yang digunakan dalam penelitian ini yaitu price to book value (PBV). Proxy yang digunakan dalam mengukur nilai sebuah perusahaan adalah price to book value.

$$
\text { PBV }=\frac{\text { Harga Pasar Saham Biasa }}{\text { Nilai Buku Per Saham }}
$$

\section{Kebijakan Dividen}

Riyanto (2011: 267) menyatakan bahwa kebijakan dividen dipengaruhi oleh kebutuhan dana untuk membayar utang yang berdampak pada pembayaran dividen, apabila perusahaan mampu melunasi hutang-hutangnya, maka perusahaan juga akan mampu membagikan dividen. Kebijakan dividen diproksikan menggunakan dividend payout ratio, (Brigham dan Houston, 2001) dalam (Fenandar, 2012). Rumus yang digunakan adalah :

$$
\mathrm{DPR}=\frac{D P S}{E P S}
$$

\section{Deskripsi Subjek dan Objek Penelitian}

Metode pengambilan sampel dilakukan dengan menggunakan purposive sampling yang telah memenuhi syarat sampel berikut:

a. Perusahaan yang terdaftar dalam Bursa Efek Indonesia dan tergolong dalam sub sektor kimia yang menerbitkan laporan keuangan selama 10 tahun berturut-turun (2009-2018)

b. Perusahaan sampel memiliki data yang lengkap yang diperlukan dalam penelitian seperti sales, total debt, total asset, net income, total outstanding share, market share, dividen serta data-data yang dibutuhkan untuk pengukuran variabel dalam penelitian ini.

c. Perusahaan yang menyajikan laporan keuangan dalam satuan mata uang rupiah

d. Perusahaan yang memiliki penjualan dengan nilai nol (0) dibuang dalam penelitian ini.

e. Dari seluruh populasi perusahaan pada sub sektor kimia tersebut mengalami eliminasi berdasarkan pada kriteria - kriteria tersebut sehingga ditetapkan sampel penelitian sebanyak 5 perusahaan. Kode dari 5 perusahaan yang telah menjadi sampel antara lain yaitu: DPNS, EKAD, ETWA, INCI, SRSN.

Objek yang menjadi fokus utama dalam penelitian ini adalah firm value (PBV), market value (EPS), leverage (DER), assets management (TATO) dan kebijakan dividen (DPR) sebagai variabel moderasi. Data yang digunakan dalam penelitian ini diperoleh dari laporan keuangan perusahaan melalui website Bursa Efek Indonesia (www.idx.co.id) pada periode tahun 2009-2018. Berdasarkan kriteria yang telah ditentukan sebelumnya pada objek penelitian, diperoleh sampel sebanyak 5 perusahaan.

\section{Metode Penelitian}

Teknik analisis yang digunakan dalam penelitian meliputi Chow Test, Hausman Test, dan pengujian hipotesis

Uji Chow digunakan untuk menentukan model manakah yang lebih baik antara pooled least square (common effect model) atau fixed effect model untuk digunakan sebagai model regresi data panel. Jika prob. Cross-section $\mathrm{F}$ kurang dari 5\% artinya fixed effect model lebih baik daripada common effect model.

Uji Hausman digunakan untuk menentukan model manakah yang lebih baik antara Random effect model atau Fixed Effect model untuk digunakan sebagai model regresi data 
panel. Jika prob. Cross-section random kurang dari 5\% maka fixed effect model lebih baik dari pada random Effect model.

Pengujian hipotesis dalam penelitian ini dapat diukur dari goodness of fit fungsi regresinya. Secara statistik, analisa ini dapat diukur dari nilai uji t, nilai uji $F$, dan koefisien determinasi. Analisa regresi ini bertujuan untuk mengetahui secara parsial maupun simultan pengaruh variabel independen terhadap variabel dependen serta untuk mengetahui proporsi variabel independen dalam menjelaskan perubahan variabel dependen.

\section{Analisis \& Bahasan Temuan}

Berdasarkan hasil pengujian dan analisis data mengenai pengaruh market value, leverage, asset management, terhadap firm value dengan kebijakan dividen sebagai variabel moderasi yang dilakukan pada 5 perusahaan sub sektor kimia yang terdaftar di Bursa Efek Indonesia periode 2009 - 2018, maka kesimpulan yang diperoleh adalah sebagai berikut:

1. Market value, leverage, asset management, terhadap firm value dengan kebijakan dividen sebagai variabel moderasi secara bersama - sama berpengaruh signifikan terhadap firm value pada perusahaan sektor kimia yang terdaftar dalam Bursa Efek Indonesia.

2. Market value yang diproksikan dengan earning per share secara parsial berpengaruh negatif dan signifikan terhadap firm value pada perusahaan sektor kimia yang terdaftar dalam Bursa Efek Indonesia.

3. Leverage yang diproksikan dengan debt to equity ratio secara parsial berpengaruh secara positif dan signifikan terhadap firm value pada perusahaan sektor kimia yang terdaftar dalam Bursa Efek Indonesia.

4. Asset management yang diproksikan dengan total assets turnover secara parsial berpengaruh positif dan signifikan terhadap firm value pada perusahaan sektor kimia yang terdaftar dalam Bursa Efek Indonesia.

5. Efek moderasi kebijakan dividen dengan variabel leverage secara parsial berpengaruh negatif dan signifikan terhadap firm value pada perusahaan sektor kimia yang terdaftar dalam Bursa Efek Indonesia.

\section{Daftar Pustaka}

Brigham, E. F., dan J. F. Houston. 2001. Manajemen Keuangan. Edisi Bahasa Indonesia. Jakarta: Erlangga.

Ekaprastyana, Devy dan Saiful Anwar. (2017). The Effect of Earning Per Share and Debt to Asset Ratio on Firm's Value : Case Study on Food and Beverage Corporation Listed in Indonesia Stock Exchange. Jurnal Keuangan dan Perbankan Vol 13 No. 2 Juni 2017: 120-127 ISSN 2579-485X.

Erawati, Diana. (2015). Pengaruh Likuiditas, Manajemen Aset, Manajemen Liabilitias, dan Profitabilitas Terhadap Harga Saham Pasar/Buku Pada Perusahaan Makanan dan Minuman Yang Terdaftar di BEI Periode Tahun 2008 - 2012. e-Jurnal Ilmu Manajemen MAGISTRA Vol. 1 No.1 Februari 2015 E-ISSN: 2442-4315

Fama, Eugene and Kenneth French. 1998. Value versus Growth: The International Evidence. Journal of Finance.

Islam, et al. (2014). How Earning per Share (EPS) Affects on Share Price and Firm Value. European Journal of Business and Management Vol. 6, No. 17. ISSN 2222-2839.

Kurniasari, Mitta Putri. (2017). Pengaruh Profitabilitas, Rasio Aktivitas, dan Leverage Terhadap Nilai Perusahaan Manufaktur di BEI. Jurnal Ilmu dan Riset Manajemen Volume 6, Nomor 8, Agustus 2017. ISSN : 2461-0593

Mindra, Sukma dan Teguh Erawati.2014. pengaruh Earning Per Share, ukuran perusahaan/ size, Profitabilitas dan Leverage terhadap nilai perusahaan pada perusahaan 
manufaktur yang terdaftar di BEI periode 2009-2011.Jurnal Akuntansi.Vol 2.No 2. Yogyakarta: Universitas Sarjanawiyata Taman Siswa Yogyakarta

Nuraeni, Elfreda Aphonia Lau, Rina Masyithoh Haryadi. 2016. Pengaruh Earning Per Share (EPS), Ukuran Perusahaan, Profitabilitas, dan Leverage Terhadap Nilai Perusahaan. Jurusan Akuntansi. Fakultas Ekonomi, Universitas 17 Agustus 1945

Prasetyorini, Bhekti Fitri.2013. pengaruh ukuran perusahaan, leverage, Price Earning Ratio, dan profitabilitas terhadap nilai perusahaan. Jurusan Manajemen, Fakultas Ekonomi, Universitas Negeri Surabaya.

Pratama, I Gusti Bagus Angga \& I Gusti Bagus Wiksuana. 2016. Pengaruh Ukuran Perusahaan dan Leverage Terhadap Nilai Perusahaan dengan Probabilitas sebagai Variabel Mediasi. E-Jurnal Manajemen Unud, Vol. 5, No. 2, 2016: 1338-1367 ISSN : 2302-8912

Putra, Nyoman Wedana Adi 2014.Pengaruh Faktor Fundamental Pada Nilai Perusahaan Sektor Telekomunikasi di Bursa Efek Indonesia. E-Jurnal Akuntansi Universitas Udayana. 8.3 (2014): 385-407.

Raharjo, Putri Andhika. 2016. Pengaruh Keputusan Pendanaan dan Ukuran Perusahaan Terhadap Nilai Perusahaan Terhadap Nilai Perusahaan dengan Kebijakan Dividen Sebagai Variabel Moderasi. Jurusan Manajemen, Fakultas Ekonomi, Universitas Negeri Yogyakarta.

Riyanto, Bambang. 2011. Dasar-Dasar Pembelanjaan Peusahaan. Edisi Keempat. Yogyakarta: BPFE

Sudana, I Made. 2011. Manajemen Keuangan Perusahaan Teori Dan Praktik. Jakarta: Erlangga.

Sukma Mindra dan Teguh. 2014. PengaruhEarning Per Share (EPS), Ukuran Perusahaan, Profitabilitas, dan Leverage Terhadap Nilai Perusahaan. Jurnal AkuntansiFakultas Ekonomi Universitas Sarjanawiyata Tamansiswa Yogyakarta, Vol. 2, No. 2, Desember 2012, Hal. 10-22.ISSN: 2088-768X.

Winarto, Jacinta. (2015). The Determinants of Manufacturer Firm Value in Indonesia Stock Exhange. International Journal of Information, Business and Management, Vol 7, No. 4, 2015

Website BEI : www.idx.co.id 